\title{
Comparison of Liver Histopathology with Non-invasive Inflammation Markers as Neutrophil-lymphocyte Ratio, Platelet-lymphocyte Ratio and Mean Platelet Volume in Chronic Hepatitis B Patients
}

\author{
Kronik Hepatit B Hastalarında Karaciğer Histopatolojisi ile Non-invaziv Enflamasyon \\ Belirteçleri Nötrofil-lenfosit Oranı, Trombosit-lenfosit Oranı, Ortalama Trombosit \\ Hacminin Karșılaștırılması
}

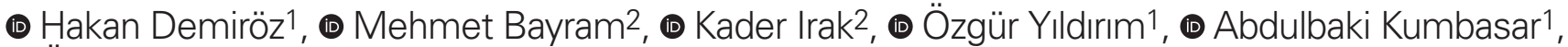 \\ (1) Ömür Tabak ${ }^{1}$
}

1 University of Health Sciences Turkey, Kanuni Sultan Süleyman Training and Research Hospital, Clinic of Internal Medicine, Istanbul, Turkey

2 University of Health Sciences Turkey, Kanuni Sultan Süleyman Training and Research Hospital, Clinic of Gastroenterology, Istanbul, Turkey

\begin{abstract}
Objectives: Platelet-lymphocyte ratio (PLR) and neutrophillymphocyte ratio (NLR) are commonly studied non-invasive inflammatory markers in cancer patients. There are some studies showing its association with fibrosis in patients with non-alcoholic steatohepatitis and chronic hepatitis B (CHB). The aim of this study is to examine the relationship between liver histopathology and viral load parameters with NLR, PLR and mean platelet volume (MPV) in patients with $\mathrm{CHB}$.

Materials and Methods: Two hundred twenty-four CHB patients who admitted to our clinic between 2016 and 2019 and underwent liver biopsy were analysed retrospectively. Study data were obtained from patient files and electronic records.

Results: The mean values in complete blood count were MPV: $10.39 \pm 1.114 \mathrm{fL}$, NLR: $2.093 \pm 1.048$ and PLR: $106.228 \pm 37.451$. The mean fibrosis score in liver biopsies was $1.38 \pm 1.07$ and the histological activity index (HAl) was $5.88 \pm 2.27$. There was a statistical significant relationship between MPV and fibrosis $(r=0.244, p=0.005), H B V-D N A$ and HAl $(r=0.296, p=0.001)$, HBV-DNA and fibrosis $(r=0.278, p=0.001)$ in men. There was no statistical significant difference between the genders in terms of
\end{abstract}

$\ddot{0 Z}$

Amaç: Trombosit-lenfosit oranı (PLR) ve nötrofil-lenfosit oranı (NLR) kanser hastalarında yaygın araştıılan non-invaziv enflamasyon belirteçleri olup; non-alkolik steatohepatit ve kronik hepatit B'li (KHB) hastalarda fibrozis ile ilişkisini gösteren bazı çalışmalar bulunmaktadır. Amacımız, KHB'li hastalarda karaciğer histopatolojisi ve viral yük parametrelerinin; NLR, PLR ve ortalama trombosit hacmi (MPV) ile olan ilişkisini incelemektir.

Gereç ve Yöntemler: Iç hastalıkları ve gastroenteroloji polikliniğine 2016-2019 yılları arasında başvuran karaciğer biyopsisi yapılan 224 KHB hastası geriye dönük incelendi. Çalışma verileri, hasta dosyaları ve elektronik kayıtlardan elde edildi.

Bulgular: Tam kan sayımında MPV: 10,39 $\pm 1,114 \mathrm{fL}$, NLR: $2,093 \pm 1,048$ ve PLR: $106,228 \pm 37,451$ idi. Karaciğer biyopside fibrozis skoru: 1,38 $\pm 1,07$ ve histolojik aktivite indeksi (HAl): $5,88 \pm 2,27$ olarak saptandı. Erkeklerde MPV ile fibrozis arasında $(r=0,244, p=0,005)$, HBV-DNA ve HAl arasında $(r=0,296, p=0,001)$, HBV-DNA ve fibrozis $(r=0,278, p=0,001)$ arasında anlamlı bir ilişki saptanmıştır. İki grup arasında fibrozis skorları ve enflamatuvar parametreler açısından anlamlı farkllık gözlenmemiştir. HAl $<6$ ve histolojik aktivite indeksi $\geq 6$; fibrosis $<2$ ve fibrozisf $\geq 2$ ve

Demiröz H, Bayram M, Irak K, Yıldırım 0̈, Kumbasar A, Tabak Ö. Comparison of Liver Histopathology with Non-invasive Inflammation Markers as NeutrophilIymphocyte Ratio, Platelet-lymphocyte Ratio and Mean Platelet Volume in Chronic Hepatitis B Patients. Viral Hepat J. 2021;27:1-5. 


\section{ABSTRACT}

fibrosis scores and inflammatory parameters. Non-invasive markers didn't make a statistical significant difference according to $\mathrm{HAl}<6$ and $\mathrm{HAI} \geq 6$, fibrosis $<2$ and fibrosis $\geq 2$ and HBV-DNA $<20,000$ and HBV-DNA $\geq 20,000$ ( $p>0.05$ ).

Conclusion: It has been determined that MPV may be a useful marker for predicting fibrosis in patients with $\mathrm{CHB}$, but further studies are needed to replace liver biopsy. Continuous monitoring of MPV will contribute to disease surveillance. NLR and PLR weren't found to be an important marker for evaluating fibrosis.

Keywords: Chronic hepatitis B, liver biopsy, non-invasive marker

\section{OZZ}

HBV-DNA $<20.000$ ve HBV-DNA $\geq 20.000$ olma durumuna göre; non-invaziv belirteçler anlamlı bir farklılık oluşturmamıştır ( $p>0,05)$. Sonuç: KHB'li hastalarda MPV'nin fibrozis tahmin etmede yardımcı bir belirteç olabileceği, fakat karaciğer biyopsisi yerini tutabilmesi için ek çalışmaya gerek olduğu saptanmıştır. MPV'nin sürekli izlenmesi, hastalık sürveyansına katkıda bulunacaktır. NLR ve PLR fibrozisi değerlendirmede önemli bir belirteç olarak bulunmamıştır.

Anahtar Kelimeler: Kronik hepatit B, karaciğer biyopsisi, non-invaziv belirteç

\section{Introduction}

Chronic hepatitis B $(\mathrm{CHB})$ is a disease that affects 240 million people worldwide and progresses from asymptomatic carriage to cirrhosis and hepatocellular cancer. Although antiviral therapy significantly reduces the risk of fibrosis and cirrhosis, some patients may develop advanced fibrosis and cirrhosis. The treatment decision in $\mathrm{CHB}$ patients is made according to serum hepatitis $\mathrm{B}$ virus (HBV)-DNA levels, alanine aminotransferase levels and the degree of necroinflammation in liver biopsy and the stage of fibrosis. Although biopsy is generally safe, it is invasive, has contraindications, can cause complications, requires hospitalization, causes sampling errors, and has a high cost. Therefore the development of easier, cheaper and non-invasive tests to show liver histopathology has become important (1). Neutrophil-lymphocyte ratio (NLR), plateletlymphocyte ratio PLR and mean platelet volume (MPV) are simple, inexpensive and reproducible non-invasive markers of inflammation that can be easily obtained from hemogram results. Among these markers, studies have shown that NLR guides the prognosis and treatment response of various diseases such as cardiovascular diseases, cancer and postoperative infection (2). NLR is thought to be a guide in predicting mortality when there is liver failure in acute or chronic viral hepatitis, and in determining HCC recurrence after liver transplantation. In compensated cirrhosis, high NLR is an exemplary model, such as Model for End-Stage Liver Disease and Child-Pugh scores, independent of mortality (3). There are many studies on PLR in inflammatory diseases, malignancy, hypertension, diabetes mellitus and autoimmune diseases (4). MPV reflects platelet function and increased platelet activation. It is also an inflammation marker (5). Recently, many studies have been conducted on the role of MPV in the differential diagnosis of familial mediterranean fever and irritable bowel syndrome, its association with coronary artery disease risk factors, and its use as an inflammatory marker in ulcerative colitis, rheumatoid arthritis and ankylosing spondylitis (6). In our study, we retrospectively investigated the relationship between fibrosis, histological activity index (HAl) scores and viral load and NLR, PLR and MPV levels in patients who underwent liver biopsy.

\section{Materials and Methods}

We retrospectively examined 224 patients who admitted to the Clinics of Internal Medicine and Gastroenterology Outpatient, University of Health Sciences Turkey, Kanuni Sultan Süleyman
Training and Research Hospital between 2016 and 2019 and underwent liver biopsy with a diagnosis of $\mathrm{CHB}$. According to the Ishak scoring system, fibrosis and $\mathrm{HAl}$ scores in the liver biopsies of the patients and NLR, PLR, MPV, hepatitis B surface antigen, hepatitis $\mathrm{B}$ e antigen ( $\mathrm{HbeAg}$ ), anti-HBe, HBV-DNA values before biopsy were obtained. Patients were divided into groups with fibrosis score $<2$ and $\geq 2$ and HAl score $<6$ and $\geq 6$. This study was approved by the Local Ethical Committee of Haseki Training and Research Hospital (approval number: 2009-49, date: 27.11.2019). Informed consent of patients couldn't obtained due to retrospective design of study.

\section{Statistical Analysis}

SPSS Statistics 15.0 was used for statistical analysis. Parameter distribution was examined with Kolmogorov-Smirnov test and interpreted parametric-non-parametrically. Comparisons of numerical variables between two independent groups were evaluated using the Student's t-test when the normal distribution condition was provided and the Mann-Whitney $U$ test when it was not provided. Relationships between numerical variables were analysed using Pearson correlation analysis when parametric test condition was provided and Spearman correlation analysis when it was not provided. Statistical significance level was accepted as $\mathrm{p}<0.05$.

\section{Results}

In our study, 93 of $\mathrm{CHB}$ patients were female (41.52\%) and 131 were male $(58.48 \%)$. The mean age of the patients was found to be 42.4 (Table 1).

No statistically significant relationship was found between HAI and fibrosis scores in biopsy results with NLR, MPV and PLR as inflammatory parameters.

There was no significant difference between the groups formed according to $\mathrm{HAl}<6$ and $\mathrm{HAl} \geq 6$ in terms of MPV, NLR and PLR variables ( $p>0.05$ ) (Table 2).

There was no statistically significant difference between the groups formed according to the fibrosis score in terms of MPV, NLR and PLR variables ( $p>0.05$ ) (Table 3).

A statistically significant relationship was found between MPV and fibrosis ( $r=0.244, p=0.005)$, HBV-DNA and HAl $(r=0.296$, $p=0.001)$, and HBV-DNA and fibrosis $(r=0.278, p=0.001)$ in male patients. There was a positive correlation between MPV value and fibrosis score in male patients. The HAl score in the biopsy results 
was found to be statistically significantly higher in the $\mathrm{HBeAg}$ positive group compared to the negative group ( $p=0.012)$. There was no statistically significant difference between the two groups in terms of fibrosis scores and inflammatory parameters (Table 4).

\section{Discussion}

Starting treatment in $\mathrm{CHB}$ is important to prevent complications such as fibrosis and HCC. In our country, after evaluating the liver function tests and viral load of patients in $\mathrm{CHB}$, liver biopsy is required to start antiviral treatment. Liver biopsy is an invasive procedure and complications such as bleeding may occur. For this reason, the efficacy of tests without risk of complications in patients is being investigated to determine liver fibrosis (7). NLR and PLR, which are easily requested, simple and practical values in routine examinations, have become important as markers of liver fibrosis with various studies. In the study of Yeşil et al. (8) it was shown that there was a relationship between NLR and fibrosis and it was thought that NLR could be a cheap fibrosis marker.

\begin{tabular}{|c|c|c|c|c|c|c|}
\hline & Number & Minimum & Maximum & Mean & Standard deviation & Median \\
\hline Age & 224 & 20 & 79 & 42.4 & 12.3 & 42 \\
\hline AST & 224 & 11 & 659 & 42.7 & 68.4 & 24.5 \\
\hline ALT & 224 & 8 & 1149 & 64.5 & 116.6 & 30 \\
\hline HBV-DNA & 224 & 0 & $2.10^{7}$ & $9.10^{6}$ & $1.3 .10^{6}$ & 21165 \\
\hline MPV & 224 & 6.3 & 15.2 & 10.3 & 1.1 & 10.3 \\
\hline NLR & 224 & 0.4 & 7.4 & 2.0 & 1.0 & 10.3 \\
\hline PLR & 224 & 31 & 254 & 106.2 & 37.4 & 101.2 \\
\hline $\mathrm{HAl}$ & 224 & 1 & 14 & 5.8 & 2.2 & 6 \\
\hline Fibrosis & 224 & 0 & 6 & 1.3 & 1.0 & 1 \\
\hline
\end{tabular}

Table 2. Evaluation of patients' inflammatory parameters according to the HAl score

\begin{tabular}{|l|l|l|l|}
\hline & HAI $<\mathbf{6}(\mathbf{n}=\mathbf{8 3})$ (median) & HAI $\geq \mathbf{6}(\mathbf{n = 1 4 1 )}$ (median) & $\mathbf{p}$ \\
\hline MPV & 10.30 & 10.30 & 0.834 \\
\hline NLR & 1.840 & 1.833 & 0.610 \\
\hline PLR & 105.556 & 100.000 & 0.218 \\
\hline HAI: Histological activity index, MPV: Mean platelet volume, NLR: Neutrophil-lymphocyte ratio, PLR: Platelet-lymphocyte ratio \\
\hline
\end{tabular}

Table 3. Evaluation of inflammatory parameters of the patients according to the fibrosis score

\begin{tabular}{|l|l|l|l|}
\hline & Fibrosis <2 (n=135) (median) & Fibrosis 2 (n=89) (median) & $\mathbf{p}$ \\
\hline MPV & 10.200 & 10.500 & 0.071 \\
\hline NLR & 1.780 & 1.880 & 0.136 \\
\hline PLR & 102.400 & 100.400 & 0.209 \\
\hline MPV: Mean platelet volume, NLR: Neutrophil-lymphocyte ratio, PLR: Platelet-lymphocyte ratio & \\
\hline
\end{tabular}

Table 4. Evaluation of the relationship of inflammatory parameters with biopsy scores by gender

\begin{tabular}{|c|c|c|c|c|c|c|c|}
\hline \multicolumn{4}{|c|}{ Female $(n=93)$} & \multicolumn{4}{|c|}{ Male $(n=131)$} \\
\hline \multicolumn{2}{|l|}{ Parameter } & HAI & Fibrosis & \multicolumn{2}{|l|}{ Parameter } & HAI & Fibrosis \\
\hline \multirow{2}{*}{ MPV } & $r$ & -0.106 & -0.027 & \multirow{2}{*}{ MPV } & $r$ & 0.099 & 0.244 \\
\hline & $\mathrm{p}$ & 0.314 & 0.798 & & $\mathrm{p}$ & 0.261 & 0.005 \\
\hline \multirow{2}{*}{ NLR } & $r$ & 0.062 & 0.049 & \multirow{2}{*}{ NLR } & $r$ & 0.008 & 0.062 \\
\hline & $\mathrm{p}$ & 0.556 & 0.644 & & $\mathrm{p}$ & 0.925 & 0.485 \\
\hline \multirow{2}{*}{ PLR } & $r$ & 0.008 & -0.199 & \multirow{2}{*}{ PLR } & $r$ & -0.038 & -0.017 \\
\hline & $p$ & 0.938 & 0.056 & & $\mathrm{p}$ & 0.667 & 0.850 \\
\hline \multirow{2}{*}{ HBV-DNA } & $r$ & 0.121 & -0.002 & \multirow{2}{*}{ HBV-DNA } & $r$ & $0.296 *$ & $0.278^{*}$ \\
\hline & $\mathrm{p}$ & 0.247 & 0.984 & & $p$ & 0.001 & 0.001 \\
\hline
\end{tabular}


Uluca et al. (9) could not detect a significant relationship between NLR and HAl-fibrosis scores in biopsies in CHB patients. Atay (10) did not detect a statistically significant difference in NLR levels in mild and advanced fibrosis patient groups. Similarly, in the study conducted by Chen et al. (11) there was no statistical significant difference between the $\mathrm{CHB}$ group and the control group. In our study, there was no statistically significant relationship between NLR, PLR and MPV values as non-invasive parameters and HAl-fibrosis scores. In the study of Yilmaz et al. (12) a statistically significant relationship was found between NLR and fibrosis stage. Zhao et al. (13) stated in their study of 172 patients that PLR and NLR have an important role in the management of $\mathrm{CHB}$ disease. It was shown in the study that NLR can be used to detect disease progression in compensated cirrhotic patients. In our study, we could not find such a result because there were very few patients with advanced fibrosis and compensated cirrhosis.

Lymphomononuclear cells are the main responsible cells for inflammation in CHB (14). Accurate results may not be obtained by evaluating mononuclear inflammation in the tissue with NLR. In the literature, when the relationship between NLR-fibrosis in $\mathrm{CHB}$ patients is evaluated, there are studies in which both positive and negative correlations were observed and there were studies in which no relationship was found between the two parameters as in our study. These different results can be explained by the fact that NLR is a variable parameter and is affected by many factors. Therefore, future studies are needed to evaluate the value of PLR and NLR in predicting clinically significant fibrosis in $\mathrm{CHB}$ patients with normal liver function test levels. Consequently with the current data, it is thought that NLR and PLR may not be an important test in determining fibrosis in patients with $\mathrm{CHB}$ and future studies are needed in this area.

It has been found that there is an association between fibrosis and MPV in patients with chronic hepatitis. In the study conducted by Purnak et al. (15) in 59 patients with $\mathrm{CHB}$, it was argued that there was a correlation between fibrosis level and MPV value and that MPV could be a non-invasive marker in patients with $\mathrm{CHB}$. In the study conducted by Ekiz et al. (16) MPV was found to be higher in $\mathrm{CHB}$ patients compared to the control group. Similarly in our study, we found a significant relationship between MPV and fibrosis in male patients. Assuming that iron deficiency anemia is more common in women and MPV is high, this may be the reason why no significant relationship about MPV could be reached in female patients in our study.

\section{Study Limitations}

The limitations of our study were that it was a retrospective study and a single center experience.

\section{Conclusion}

Although liver biopsy in $\mathrm{CHB}$ has some disadvantages, it is the gold standard method in the follow-up and treatment of the disease. However in cases where liver biopsy is not possible, there is a need to use non-invasive markers to evaluate fibrosis. Although there was no significant relationship between NLR and PLR and fibrosis in our study, it is thought that MPV may be an important parameter in determining the patient group with advanced fibrosis in $\mathrm{CHB}$. Further studies that are more comprehensive and with larger numbers of patients are needed to evaluate MPV changes in $\mathrm{CHB}$ patients.

\section{Ethics}

Ethics Committee Approval: This study was approved by the Local Ethical Committee of Haseki Training and Research Hospital (approval number: 2009/49, date: 27.11.2019).

Informed Consent: Informed consent of patients couldn't obtained due to retrospective design of study.

Peer-review: Externally peer-reviewed.

\section{Authorship Contributions}

Surgical and Medical Practices: A.K., Ö.T., Ö.Y., M.B., K.I., H.D., Concept: A.K., Ö.T., Ö.Y., M.B., K.I., H.D., Design: A.K., Ö.T., Ö.Y., M.B., K.I., H.D., Data Collection or Processing: H.D., Analysis or Interpretation H.D., Literature Search: M.B., K.I., H.D., Writing: A.K., Ö.T., Ö.Y., M.B., K.I., H.D.

Conflict of Interest: The authors of this article declare that they have no conflict of interest.

Financial Disclosure: The authors declare that this study has not received any financial support.

\section{References}

1. Mardini H, Record C. Detection of assessment and monitoring of hepatic fibrosis: Biochemistry or biopsy? Ann Clin Biochem. 2005; 42:441-447

2. Gibson $\mathrm{PH}$, Croal $\mathrm{BL}$, Cuthbertson $\mathrm{BH}$, Small $\mathrm{GR}$, Ifezulike Al, Gibson G, Jeffrey RR, Buchan KG, El-Shafei H, Hillis GS. Preoperative neutrophil-lymphocyte ratio and outcome from coronary artery bypass grafting. Am Heart J. 2007;154:995-1002.

3. Leithead JA, Rajoriya N, Gunson BK, Ferguson JW. Neutrophilto-lymphocyte ratio predicts mortality in patients listed for liver transplantation. Liver Int. 2015;35:502-509.

4. Chen X, Meng Y, Shao M, Zhang T, Han L, Zhang W, Zhang H, Hai H, Li G. Prognostic Value of Pre-Infarction Angina Combined with Mean Platelet Volume to Lymphocyte Count Ratio for No-Reflow and Short-Term Mortality in Patients with ST-Segment Elevation Myocardial Infarction Undergoing Percutaneous Coronary Intervention. Med Sci Monit. 2020;26:e919300.

5. Ceylan B, Mete B, Fincanci M, Aslan T, Akkoyunlu Y, Ozguneş N, Colak O, Gunduz A, Senates E, Ozaras R, Inci A, Tabak F. A new model using platelet indices to predict liver fibrosis in patients with chronic hepatitis B infection. Wien Klin Wochenschr. 2013;125:453-460.

6. Kisacik B, Tufan A, Kalyoncu U, Karadag O, Akdogan A, Ozturk MA, Kiraz S, Ertenli I, Calguneri M. Mean platelet volume (MPV) as an inflammatory marker in ankylosing spondylitis and rheumatoid arthritis. Joint Bone Spine. 2008;75:291-294.

7. Kaya O, Akçam FZ, Sönmez Y, Tığlı A, Çiriş M. Evaluation of Noninvasive Methods for Prediction of Fibrosis in Chronic Hepatitis B and C Infections. Viral Hepat J. 2009;14:91-97.

8. Yeşil A, Coşgun A, Erdem E, Koçhan K, Gündüz F, Gönen C. The relationship between fibrosis level and blood neutrophil to lymphocyte ratio in chronic HBV patient. Akademic Gastroenterology. 2013;12:66-68.

9. Uluca U, Sen V, Güneș A, Tan I, Aktar F, Cubuk E, Sabaz MN. Evaluation of neutrophil to lymphocyte ratio and mean platelet volume in inactive hepatitis B carriers. Mustafa Kemal Üniversitesi Tıp Dergisi 2015;6:8-13.

10. Atay K. Relationship between neutrophil-to-lymphocyte ratio, mean platelet volume, and fibrosis level in patients with chronic hepatitis B. The Turkish Journal of Academic Gastroenterology. 2019;18:7-11. 
11. Chen $L$, Lou $Y$, Chen $Y$, Yang J. Prognostic value of the neutrophilto-lymphocyte ratio in patients with acute-on-chronic liver failure. Int J Clin Pract. 2014;68:1034-1040.

12. Yilmaz B, Aydin $H$, Can G, Şentürk $Z$, Üstüner B, Yilmaz $H$, Öztürkler M, Roach EC, Korkmaz U, Kurt M, Çelebi A, Şentürk Ö, Hülagü S. The relationship between fibrosis level and blood neutrophil to lymphocyte ratio in inactive hepatitis B carriers. Eur J Gastroenterol Hepatol. 2014;26:1325-1328.

13. Zhao Z, Liu J, Wang J, Xie T, Zhang Q, Feng S, Deng H, Zhong B. Platelet-to-lymphocyte ratio (PLR) and neutrophil-to-lymphocyte ratio (NLR) are associated with chronic hepatitis $B$ virus (HBV) infection. Int Immunopharmacol. 2017;51:1-8.
14. Calvaruso V, Craxì A. Fibrosis in chronic viral hepatitis. Best Pract Res Clin Gastroenterol. 2011;25:219-230.

15. Purnak T, Olmez S, Torun S, Efe C, Sayilir A, Ozaslan E, Tenlik I, Kalkan IH, Beyazit $Y$, Yuksel O. Mean platelet volume is increased in chronic hepatitis $\mathrm{C}$ patients with advanced fibrosis. Clin Res Hepatol Gastroenterol. 2013;37:41-46.

16. Ekiz F, Yüksel O, Koçak E, Yılmaz B, Altınbaş A, Çoban S, Yüksel I, Üsküdar O, Köklü S. Mean platelet volume as a fibrosis marker in patients with chronic hepatitis B. J Clin Lab Anal. 2011;25:162165. 